\title{
TRENDS IN MORTALITY FROM CANCER OF THE UTERUS IN CANADA AND IN ENGLAND AND WALES
}

\author{
L. J. KINLEN* AND R. DOLL \\ Department of the Regius Professor of Medicine, Radcliffe Infirmary, Oxford
}

The evidence that carcinoma-in-situ of the cervix uteri commonly develops into invasive cancer is strong but inconclusive, and the prophylactic value of screening for carcinoma-in-situ in healthy women continues to be questioned. It is, therefore, of interest to see whether screening programmes are followed by any appreciable change in the mortality from cervix cancer, particularly in British Columbia, where an extensive programme has been undertaken for longer than in most other parts of the world.

Five years ago, when Ahluwalia and Doll (1968) examined the mortality rates from cancer of the uterus in Canada, they found that the rates differed little between different parts and that there was no indication of any greater reduction in mortality from cancer of the cervix in British Columbia than elsewhere. Screening was begun in British Columbia on a small scale in 1949 and six years later the number being examined each year was still only a little over 10,000 . Subsequently the number rose to over 100,000 per year, and Worth, Boyes, and Fidler (1967) estimated that $24 \%$ of all women resident in British Columbia who were over 20 years of age had been examined at least once by the end of 1960 and that $57 \%$ had been examined by the end of 1964 . In 1970, 297,000 women were screened in a total population of 664,400 women aged 20 years or over, $27 \%$ of whom were screened for the first time, and it is now estimated that approximately $80 \%$ of women over the age of 20 years have been screened (Boyes, 1972).

Even if screening was a completely prophylactic measure, three factors would have acted to prevent a corresponding reduction in mortality. First, some of the women had already developed invasive cancer at the time they were screened; secondly, the women who were examined were self-selected and it is common experience that those who come forward for examination are less at risk than those who do not; thirdly, $10 \%$ of deaths from cervix cancer occur more than five years after treatment. It might be, therefore, that the Canadian experience had not been followed for long enough to show any decisive results, and Ahluwalia and Doll (1968) were able to conclude only that if mass cytological screening was effective, a reduction in mortality should be seen in the next few years. We have, therefore, now examined the comparable data for the six-year period 1966-71.

\section{Method AND Results}

Mortality rates for cancer of the cervix uteri and for other cancers of the uterus in Canada are shown in Tables I and II for the years 1966 to 1971 . Figures are given separately for British Columbia, Ontario,

\footnotetext{
* Cancer Research Campaign Gibb Fellow
}

TABLE I

STANDARDIZED MORTALITY RATES FROM CANCER OF THE CERVIX UTERI IN PARTS OF CANADA, 1966-71

\begin{tabular}{|c|c|c|c|c|c|c|c|c|}
\hline \multirow[b]{2}{*}{ Age Group (yr) } & \multirow[b]{2}{*}{ Area } & \multicolumn{6}{|c|}{ Standardized Mortality per 100,000 Women in } & \multirow{2}{*}{$\begin{array}{l}\text { No. of Deaths } \\
\text { in } 1971\end{array}$} \\
\hline & & 1966 & 1967 & 1968 & 1969 & 1970 & 1971 & \\
\hline $20-44$ & $\begin{array}{l}\text { British Columbia } \\
\text { Ontario } \\
\text { Rest of Canada }\end{array}$ & $\begin{array}{l}2 \cdot 4 \\
3 \cdot 7 \\
3 \cdot 9\end{array}$ & $\begin{array}{l}3 \cdot 0 \\
4 \cdot 0 \\
3 \cdot 9\end{array}$ & $\begin{array}{l}3 \cdot 8 \\
2 \cdot 8 \\
3 \cdot 3\end{array}$ & $\begin{array}{l}2 \cdot 9 \\
3 \cdot 7 \\
3 \cdot 5\end{array}$ & $\begin{array}{l}2 \cdot 0 \\
2 \cdot 4 \\
3 \cdot 5\end{array}$ & $\begin{array}{l}4.6 \\
2.9 \\
3.9\end{array}$ & $\begin{array}{l}16 \\
38 \\
74\end{array}$ \\
\hline $45-64$ & $\begin{array}{l}\text { British Columbia } \\
\text { Ontario } \\
\text { Rest of Canada }\end{array}$ & $\begin{array}{l}20 \cdot 3 \\
18 \cdot 1 \\
17 \cdot 6\end{array}$ & $\begin{array}{l}12 \cdot 8 \\
17 \cdot 2 \\
17 \cdot 9\end{array}$ & $\begin{array}{l}14 \cdot 6 \\
18 \cdot 8 \\
13 \cdot 6\end{array}$ & $\begin{array}{l}13 \cdot 1 \\
14 \cdot 8 \\
14 \cdot 7\end{array}$ & $\begin{array}{l}10.9 \\
18 \cdot 4 \\
15 \cdot 5\end{array}$ & $\begin{array}{l}12.7 \\
12.9 \\
15.9\end{array}$ & $\begin{array}{r}28 \\
96 \\
169\end{array}$ \\
\hline $65+$ & $\begin{array}{l}\text { British Columbia } \\
\text { Ontario } \\
\text { Rest of Canada }\end{array}$ & $\begin{array}{l}22 \cdot 8 \\
30 \cdot 6 \\
27 \cdot 2\end{array}$ & $\begin{array}{l}16 \cdot 5 \\
23 \cdot 9 \\
23 \cdot 7\end{array}$ & $\begin{array}{l}21 \cdot 5 \\
28 \cdot 6 \\
25 \cdot 9\end{array}$ & $\begin{array}{l}31 \cdot 2 \\
26 \cdot 2 \\
23 \cdot 2\end{array}$ & $\begin{array}{l}25 \cdot 8 \\
23 \cdot 7 \\
25 \cdot 1\end{array}$ & $\begin{array}{l}19 \cdot 5 \\
18 \cdot 3 \\
22 \cdot 7\end{array}$ & $\begin{array}{r}25 \\
68 \\
115\end{array}$ \\
\hline
\end{tabular}


TABLE II

STANDARDIZED MORTALITY RATES FROM CANCER OF THE CORPUS UTERI AND UTERUS UNDEFINED IN PARTS OF CANADA, $1966-71$

\begin{tabular}{|c|c|c|c|c|c|c|c|c|}
\hline \multirow[b]{2}{*}{ Age Group (yr) } & \multirow[b]{2}{*}{ Area } & \multicolumn{6}{|c|}{ Standardized Mortality per 100,000 Women in } & \multirow{2}{*}{$\begin{array}{c}\text { No. of Deaths } \\
\text { in } 1971\end{array}$} \\
\hline & & 1966 & 1967 & 1968 & 1969 & 1970 & 1971 & \\
\hline $20-44$ & $\begin{array}{l}\text { British Columbia } \\
\text { Ontario } \\
\text { Rest of Canada }\end{array}$ & $\begin{array}{l}0.0 \\
0.4 \\
0.9\end{array}$ & $\begin{array}{l}0.0 \\
0.2 \\
0.7\end{array}$ & $\begin{array}{l}0.3 \\
0.2 \\
0.4\end{array}$ & $\begin{array}{l}0.0 \\
0.3 \\
0.6\end{array}$ & $\begin{array}{l}0.3 \\
0.3 \\
0.4\end{array}$ & $\begin{array}{l}0.6 \\
0.2 \\
0.6\end{array}$ & $\begin{array}{r}3 \\
3 \\
12\end{array}$ \\
\hline $45-64$ & $\begin{array}{l}\text { British Columbia } \\
\text { Ontario } \\
\text { Rest of Canada }\end{array}$ & $\begin{array}{r}8 \cdot 4 \\
8 \cdot 3 \\
11 \cdot 6\end{array}$ & $\begin{array}{l}3.7 \\
7.4 \\
9 \cdot 1\end{array}$ & $\begin{array}{l}9 \cdot 1 \\
6 \cdot 2 \\
9 \cdot 1\end{array}$ & $\begin{array}{l}6 \cdot 5 \\
4 \cdot 8 \\
9 \cdot 8\end{array}$ & $\begin{array}{r}4 \cdot 5 \\
6.9 \\
10 \cdot 5\end{array}$ & $\begin{array}{l}4 \cdot 6 \\
6 \cdot 0 \\
8 \cdot 9\end{array}$ & $\begin{array}{r}9 \\
44 \\
95\end{array}$ \\
\hline $65+$ & $\begin{array}{l}\text { British Columbia } \\
\text { Ontario } \\
\text { Rest of Canada }\end{array}$ & $\begin{array}{l}27 \cdot 6 \\
21 \cdot 9 \\
33 \cdot 4\end{array}$ & $\begin{array}{l}14 \cdot 7 \\
30 \cdot 5 \\
37 \cdot 6\end{array}$ & $\begin{array}{l}12 \cdot 7 \\
26 \cdot 9 \\
34 \cdot 1\end{array}$ & $\begin{array}{l}20 \cdot 0 \\
27 \cdot 7 \\
35 \cdot 2\end{array}$ & $\begin{array}{l}14 \cdot 0 \\
27 \cdot 7 \\
32 \cdot 3\end{array}$ & $\begin{array}{l}24 \cdot 1 \\
22 \cdot 4 \\
33 \cdot 3\end{array}$ & $\begin{array}{r}30 \\
87 \\
173\end{array}$ \\
\hline
\end{tabular}

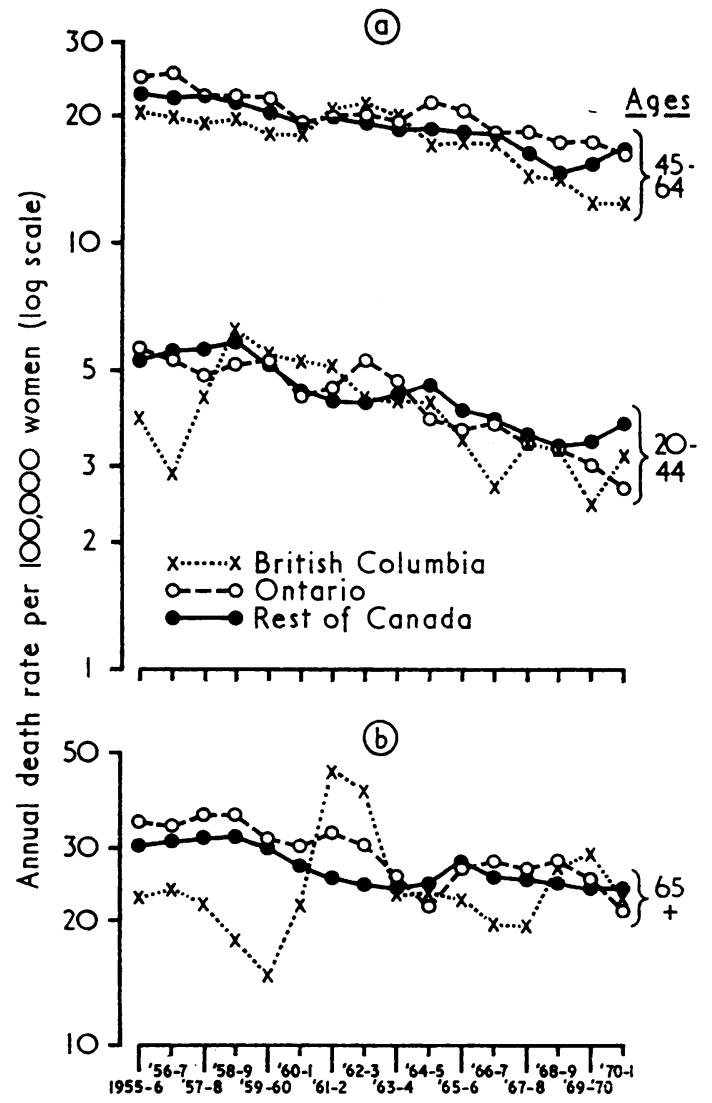

Fig. 1. Average annual death rate from cancer of the cervix uteri in British Columbia, Ontario, and other parts of Canada from 1955-56 to 1970-71, standardized for age within broad age groups: (a) ages 20 to 44 and 45 to 64 years; $(b)$ ages 65 years and over.

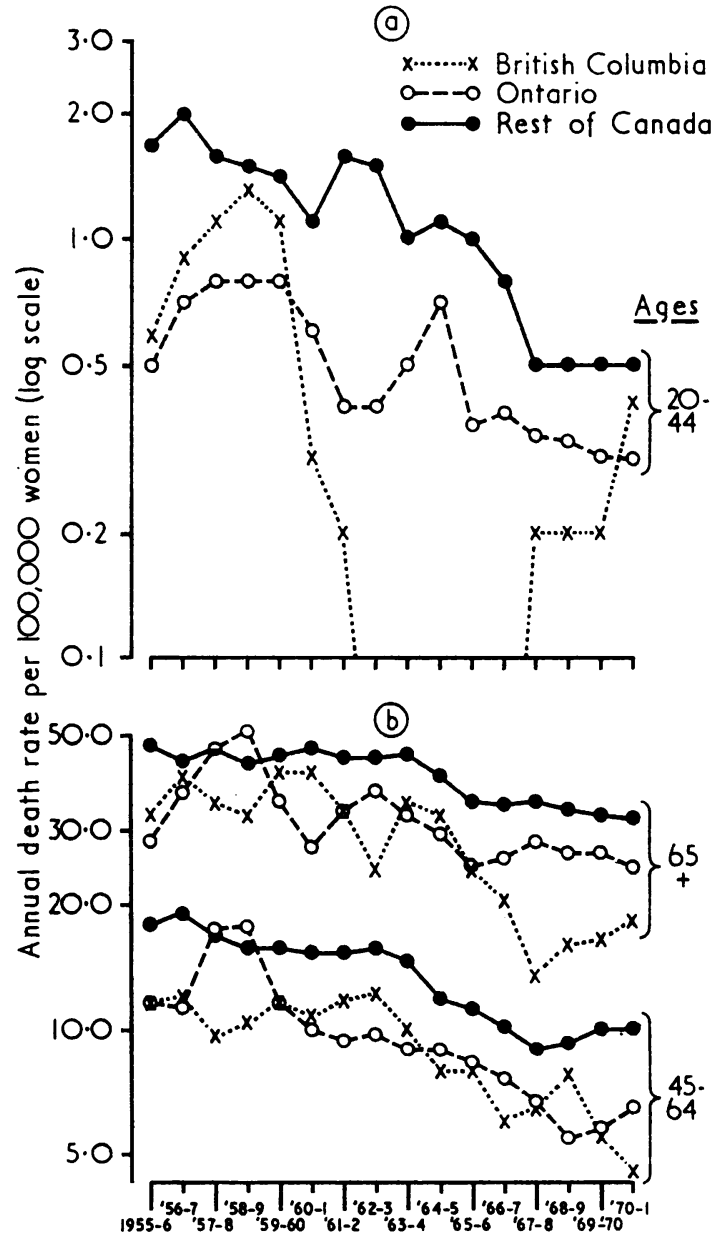

FIG. 2. Average annual death rate from cancer of the corpus uteri and other parts of the uterus not specified as cervix in British Columbia, Ontario, and other parts of Canada from 1955-56 to 1970-71, standardized for age within age groups: (a) 20 to $44 ;(b) 45$ to 64 and 65 years and over. 
and the rest of Canada in three broad age groups and are standardized for age within each age group using rounded off weights for each five-year age group derived from Segi's selected 'world population' (Doll, Muir, and Waterhouse, 1970). These rates are comparable with the rates published previously for individual years from 1955 to 1965 by Ahluwalia and Doll (1968). The trends in mortality over the whole period 1955-71 are shown in Figs. 1 and 2, in which mortality rates are averaged over consecutive years to reduce the

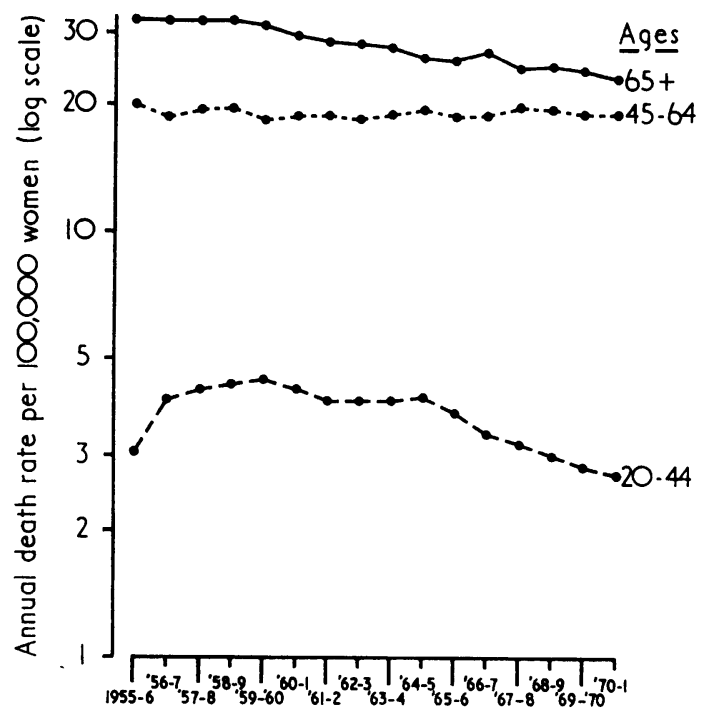

Fig. 3. Average annual death rate from cancer of the cervix uteri in England and Wales from 1955-56 to 1970-71, standardized for age within broad age groups: 20 to 44,45 to 64 , and 65 years and over. effect of random variation of small numbers.

The results show that the mortality from cervix cancer has declined materially in the last 10 years, particularly under 45 years of age, but that there is very little difference between the experience in British Columbia, Ontario, and other parts of Canada. Only at ages 45-64 does British Columbia appear to have had any appreciable advantage.

Tables III and IV and Figs. 3 and 4 show the corresponding rates for England and Wales. It will be seen that in England and Wales the mortality

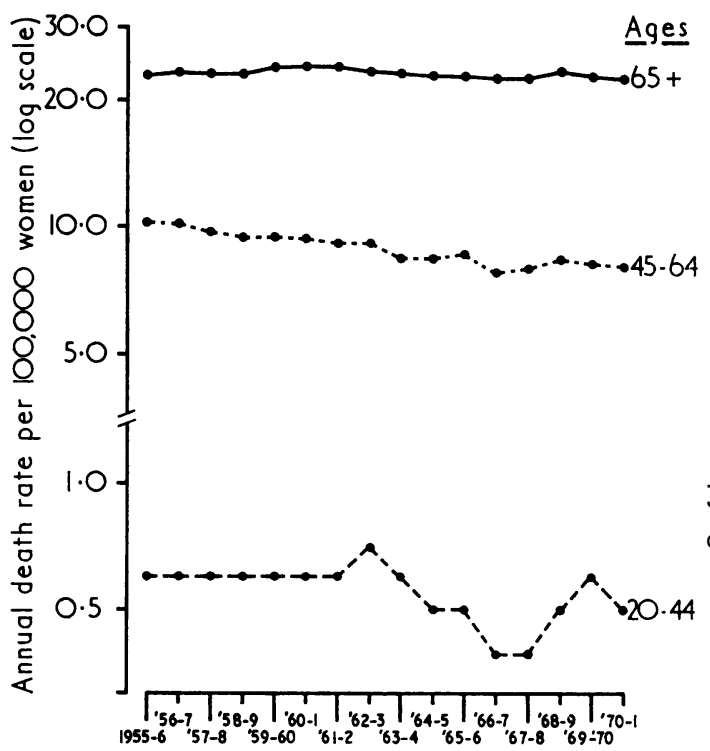

Fig. 4. Average annual death rate from cancer of the corpus uteri and other parts of the uterus not specified as cervix in England and Wales from 1955-56 to 1970-71, standardized for age within broad age groups: 20 to 44,45 to 64 , and 65 years and over.

TABLE III

STANDARDIZED MORTALITY RATES FROM CANCER OF THE CERVIX UTERI IN ENGLAND AND WALES, 1955-71

\begin{tabular}{|c|c|c|c|c|c|c|c|c|c|c|c|c|c|c|c|c|c|}
\hline \multirow[b]{2}{*}{ Age Group } & \multicolumn{17}{|c|}{ Standardized Mortality per 100,000 Women in } \\
\hline & 1955 & 1956 & 1957 & 1958 & 1959 & 1960 & 1961 & 1962 & 1963 & 1964 & 1965 & 1966 & 1967 & 1968 & 1969 & 1970 & 1971 \\
\hline $\begin{array}{l}20-44 \\
45-64 \\
65+\end{array}$ & $\begin{array}{r}3.7 \\
19 \cdot 7 \\
31 \cdot 3\end{array}$ & $\begin{array}{r}3.8 \\
19.4 \\
31.9\end{array}$ & $\begin{array}{r}4 \cdot 2 \\
18 \cdot 1 \\
30 \cdot 8\end{array}$ & $\begin{array}{r}4 \cdot 4 \\
20 \cdot 7 \\
31 \cdot 7\end{array}$ & $\begin{array}{r}4 \cdot 4 \\
18 \cdot 2 \\
31 \cdot 1\end{array}$ & $\begin{array}{r}4 \cdot 7 \\
18 \cdot 7 \\
30 \cdot 1\end{array}$ & $\begin{array}{r}3.9 \\
18.9 \\
27.9\end{array}$ & $\begin{array}{r}4 \cdot 1 \\
18 \cdot 5 \\
28 \cdot 3\end{array}$ & $\begin{array}{r}3.9 \\
18.4 \\
27.6\end{array}$ & $\begin{array}{r}4 \cdot 1 \\
19.7 \\
27.7\end{array}$ & $\begin{array}{r}4.4 \\
19.4 \\
23.6\end{array}$ & $\begin{array}{r}3 \cdot 5 \\
18 \cdot 4 \\
27 \cdot 2\end{array}$ & $\begin{array}{r}3.2 \\
19.4 \\
25 \cdot 1\end{array}$ & $\begin{array}{r}3 \cdot 1 \\
20 \cdot 1 \\
23 \cdot 7\end{array}$ & $\begin{array}{r}2 \cdot 9 \\
18 \cdot 8 \\
25 \cdot 0\end{array}$ & $\begin{array}{r}2 \cdot 6 \\
19.1 \\
23.4\end{array}$ & $\begin{array}{r}2 \cdot 8 \\
19 \cdot 1 \\
22 \cdot 4\end{array}$ \\
\hline
\end{tabular}

TABLE IV

STANDARDIZED MORTALITY RATES FROM CANCER OF THE UTERUS, EXCEPT CERVIX, IN ENGLAND AND WALES, 1955-71

\begin{tabular}{|c|c|c|c|c|c|c|c|c|c|c|c|c|c|c|c|c|c|}
\hline \multirow[b]{2}{*}{ Age Group } & \multicolumn{17}{|c|}{ Standardized Mortality per 100,000 Women in } \\
\hline & 1955 & 1956 & 1957 & 1958 & 1959 & 1960 & 1961 & 1962 & 1963 & 1964 & 1965 & 1966 & 1967 & 1968 & 1969 & 1970 & 1971 \\
\hline $\begin{array}{l}20-44 \\
45-64 \\
65+\end{array}$ & $\begin{array}{r}0.6 \\
9.9 \\
22.7\end{array}$ & $\begin{array}{r}0.6 \\
10.5 \\
22.9\end{array}$ & $\begin{array}{r}0.6 \\
9.9 \\
23.6\end{array}$ & $\begin{array}{r}0.5 \\
9.6 \\
22.7\end{array}$ & $\begin{array}{r}0.7 \\
9 \cdot 3 \\
23.7\end{array}$ & $\begin{array}{r}0.6 \\
9.4 \\
24.0\end{array}$ & $\begin{array}{r}0.6 \\
9.1 \\
24 \cdot 2\end{array}$ & $\begin{array}{r}0 \cdot 7 \\
9 \cdot 1 \\
24 \cdot 4\end{array}$ & $\begin{array}{r}0.7 \\
9.2 \\
23.1\end{array}$ & $\begin{array}{r}0.4 \\
7.8 \\
23.4\end{array}$ & $\begin{array}{r}0.6 \\
9.3 \\
23.2\end{array}$ & $\begin{array}{r}0.4 \\
8 \cdot 2 \\
23.3\end{array}$ & $\begin{array}{r}0.4 \\
7.6 \\
22.3\end{array}$ & $\begin{array}{r}0.4 \\
8.6 \\
23.5\end{array}$ & $\begin{array}{r}0.6 \\
8.4 \\
24.5\end{array}$ & $\begin{array}{r}0 \cdot 5 \\
8 \cdot 3 \\
22 \cdot 1\end{array}$ & $\begin{array}{r}0.5 \\
8 \cdot 1 \\
23 \cdot 6\end{array}$ \\
\hline
\end{tabular}


from cancer of the cervix at ages 20-44 years has been declining over the past decade, though less rapidly than in Canada. In contrast to Canada, the mortality at ages 45-64 years has remained fairly constant.

\section{Discussion}

The introduction of a free cytology service in British Columbia in 1949 was a pioneer venture which resulted in a rapid increase in the number of women who were screened each year. Certainly, screening has been carried out on a larger scale in that province than elsewhere in Canada or in England and Wales. In 1962 the number of smears taken (some of which will have been repeats) per 100 women aged 20 or over was approximately 23 in British Columbia, 3 in Ontario, and 4 in the rest of Canada (Kulcsar, 1966). (Details of the number of cervical smears in England and Wales are available only from 1964.) In 1965 the corresponding figures were 34, 12 and 11, and in England and Wales, 4, while in 1967 these approximate rates had risen to $41,23,19$, and 8 respectively (Anderson, Thompson, and Kulcsar, 1969; Reports of Chief Medical Officer for 1965 and 1967). Except for British Columbia, no figures are available of the number of women who have been screened in these areas.

The fact that the mortality from cancer of the cervix at 45-64 years of age has declined in British Columbia more than in other parts of Canada or in England and Wales is encouraging, as it is consistent with the view that prophylactic screening can reduce mortality. But it does not necessarily follow that the differences-which are far from dramatic and are not seen at other ages - can be attributed to the screening programme. Before this can be done, we must know the prevalence of hysterectomy at different ages. For a valid comparison, we need to calculate the mortality from cervical cancer after excluding those women who had had a hysterectomy for reasons unconnected with screening and cervical cancer and who therefore were not at risk of developing the disease. Unfortunately, such data were not available, but in 1968 and 1969 the age-specific hysterectomy rates within the age range $25-54$ years were $0 \cdot 16 \%$ per annum higher in British Columbia than in the rest of Canada (Dominion Bureau of Statistics, 1971; Statistics Canada, 1972; Boyes, 1973). From the available figures it can be estimated that a difference of some $5 \%$ may exist in the proportion of women aged 55 years who have had a hysterectomy (estimated prevalences at 1968 rates of $37.3 \%$ and $33.1 \%$ ). This difference is too small completely to explain the lower mortality rates in British Columbia at ages $45-64$, the more so since at least some of the excess hysterectomy rate must be attributed to the effect of the screening programme.

We wish to thank Mr. H. G. Page, Chief, Vital Statistics Section, Statistics Canada, for supplying details of deaths from cancer of the uterus in Canada, Mrs. Angela Hewitt for carrying out most of the calculations, and the Cancer Research Campaign for financial support.

\section{REFERENCES}

Ahluwalia, H. S., and Doll, R. (1968). Mortality from cancer of the cervix uteri in British Columbia and other parts of Canada. Brit. J. prev. soc. Med., 22, 161.

Anderson, G. H., Thompson, D. W., and Kulcsar, D. D. (1969). Survey of cytological facilities in Canada. Canad. med. Ass. J., 101, 279.

BOYES, D. A. (1972). In Symposium on 26 September 1972 of the British Society for Clinical Cytology.

- (1973). Personal communication.

- Worth, A. J., and FidLer, H. K. (1970). The results of treatment of 4389 cases of pre-clinical cervical squamous carcinoma. J. Obstet. Gynaec. Brit. Cwlth, 77, 769.

Doll, R., Muir, C., and Waterhouse, J. (1970). Cancer Incidence in Five Continents, Vol. 2. Union Internationale Contre le Cancer. Springer-Verlag.

Dominion Bureau of Statistics (1971). Surgical Procedures and Treatments, 1968.

Kulcsar, D. D. (1966). Survey of cytological facilities in Canada. Canad. med. Ass. J., 94, 1228.

RePORTS OF THE CHIEF MEDICAL OFFICER (1965 and 1967). H.M.S.O.

Statistics Canada (1972). Surgical Procedures and Treatments, 1969.

Worth, A. J., BOYEs, D. A., and FidLeR, H. K. (1967). The acceptance of the cervical cytology screening programme in the province of British Columbia. $J$. Obstet. Gynaec. Brit. Cwlth, 74, 479. 